\title{
EKSTRAKSI LIKOPEN DARI BUAH TOMAT (Lycopersicum Esculentum) MENGGUNAKAN PELARUT TUNGGAL DENGAN METODE KRISTALISASI ANTISOLVENT
}

\author{
Sola Fide Gavra Tarigan*, Deviana C.S. Sinaga, Zuhrina Masyithah \\ Departemen Teknik Kimia, FakultasTeknik, Universitas Sumatera Utara, \\ Jl. Almamater Kampus USU Medan 20155, Indonesia \\ *Email: fidegavra@gmail.com
}

\begin{abstract}
Abstrak
Tujuan dilakukan penelitian ini adalah untuk mengetahui pengaruh perbandingan umpan dan pelarut (f/s), jenis antisolvent dan jenis pelarut terhadap ekstraksi likopen dari buah tomat (Lycopersicum esculentum) menggunakan pelarut tunggal dengan metode kristalisasi antisolvent. Pelarut yang digunakan adalah heksana dan etil asetat serta digunakan metanol dan etanol sebagai antisolvent. Dilakukan penghalusan buah tomat kemudian diekstraksi. Kemudian ekstrak yang diperoleh ditambahkan antisolvent. Hasil penelitian menunjukkan bahwa semakin besar perbandingan umpan dan pelarut maka kadar likopen yang diperoleh akan semakin besar. Pada perbandingan umpan dan pelarut 1:4,5 dengan pelarut heksana diperoleh kadar total likopen paling tinggi yaitu $2,7 \mathrm{mg} / 150 \mathrm{ml}$ dan $2,2 \mathrm{mg} / 150 \mathrm{ml}$. Sedangkan pada perbandingan umpan dan pelarut 1:4,5 dengan pelarut etil asetat diperoleh kadar total likopen paling tinggi yaitu 3,2 $\mathrm{mg} / 150 \mathrm{ml}$ dan 2,8 mg/150 ml. Dengan penggunaan metanol sebagai antisolvent kadar likopen yang diperoleh lebih besar. Dengan penggunaan pelarut etil asetat kadar likopen yang diperoleh lebih besar.
\end{abstract}

Kata kunci : antisolvent, ekstraksi cair-cair, likopen, tomat

\begin{abstract}
This research was aimed to study the effect of feed and solvent ratio $(f / s)$, antisolvent variety and solvent variety to the extraction of lycopene from tomato (Lycopersicum esculentum)by using single solvent and antisolvent crystalization method. The solvent that used was hexane and ethyl acetate and also methanol and ethanol as the antisolvent. Tomatoes was milled and then extracted. Antisolvent then added to the extract which was obtained. The results show that the more feed and solvent ratio (f/s) the more lycopene obtained. At the ratio of 1:4,5 with hexane as the solvent obtained the highest lycopene yield were 2,7 $\mathrm{mg} / 150 \mathrm{ml}$ and 2,2 $\mathrm{mg} / 150 \mathrm{ml}$. Whereas at the ratio of 1:4,5 with ethyl acetate as the solvent obtained the highest lycopene yield were $3,2 \mathrm{mg} / 150 \mathrm{ml}$ dan $2,8 \mathrm{mg} / 150 \mathrm{ml}$. By using methanol as an antisolvent, much lycopene would be obtained. By using ethyl acetate as a solvent, much lycopene would be obtained.
\end{abstract}

Keywords : antisolvent, liquid-liquid extraction, lycopene, tomato

\section{Pendahuluan}

Tomat dan produk tomat kaya sumber vitamin $\mathrm{C}$ dan $\mathrm{A}$, likopen, $\beta$ - karoten, lutein, lektin, dan berbagai senyawa fenolik seperti flavonoid dan asam fenolat. Tomat kaya akan folat, kalium, serat, dan protein, tetapi rendah lemak dan kalori, serta bebas kolesterol. Buah tomat setelah matang sempurna akan cepat menjadi rusak/busuk yakni setelah 3-4 hari penyimpanan pada suhu kamar sehingga tanpa adanya penanganan khusus umur simpan buah tomat relatif singkat/pendek [21]. Sintesis pigmen pada tomat berkaitan dengan proses pematangan, dan warna merah pada buah merupakan hasil dari akumulasi likopen.
Selama periode pematangan, komposisi likopen pada buah meningkat tajam [23].

Dari penelitian sebelumnya, dapat disimpulkan bahwa ekstraksi likopen dari buah tomat (Lycopersicum esculentum) menggunakan metode kristalisasi antisolvent menghasilkan rendemen likopen yang lebih tinggi dibandingkan dengan metode ekstraksi cair-cair ataupun dengan metode lain. Selain dari pada itu, di Indonesia masih jarang digunakan metode kristalisasi antisolvent untuk mengekstraksi likopen dari buah tomat untuk menghasilkan rendemen ekstrak yang lebih tinggi dan juga masih kurangnya penggunaan buah tomat yang telah lewat matang. Oleh sebab itu 
digunakan buah tomat yang telah lewat matang dalam penelitian ini dengan metode kristalisasi antisolvent untuk memperoleh kandungan ekstrak likopen yang tinggi.

\section{Teori}

Pematangan tomat ditandai oleh pelunakan buah, degradasi klorofil dan peningkatan laju respirasi, produksi etilen, serta sintesis asam, gula dan likopen $[5,15]$.

Tabel 1. Kandungan Nutrisi Buah Tomat dalam 100 gram Buah Tomat [11]

\begin{tabular}{|l|l|l|}
\hline Nutrisi & Satuan & $\begin{array}{l}\text { Kadar per 100 } \\
\text { gram tomat }\end{array}$ \\
\hline Vitamin C & $\mathrm{mg}$ & 22,8 \\
\hline Vitamin B-6 & $\mathrm{mg}$ & 0,079 \\
\hline Folat & $\mu \mathrm{g}$ & 13 \\
\hline Vitamin A & $\mathrm{IU}$ & 489 \\
\hline Likopen & $\mu \mathrm{g}$ & 3.041 \\
\hline$\beta$-karoten & $\mu \mathrm{g}$ & 293 \\
\hline Lutein & $\mu \mathrm{g}$ & 94 \\
\hline Vitamin E & $\mathrm{mg}$ & 0,56 \\
\hline Vitamin K & $\mu \mathrm{g}$ & 2,8 \\
\hline
\end{tabular}

Likopen adalah karotenoid dengan rumus $\mathrm{C}_{40} \mathrm{H}_{56}$ dan memiliki berat molekul 536,85 g / mol. Rumus strukturnya adalah:

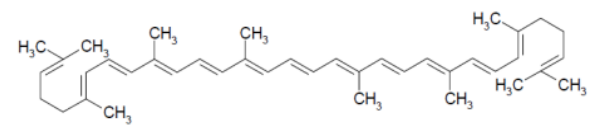

\section{Gambar 1. Rumus Struktur Likopen [4]}

Tingkat likopen buah tomat ditentukan dari potensi genetik jenisnya dan kondisi lingkungan, terutama suhu dan cahaya. Selama periode pematangan, komposisi likopen pada buah meningkat tajam [23]. Struktur terkonjugasi membuat likopen antioksidan yang sangat efektif dan mungkin juga bertanggung jawab untuk perannya dalam pencegahan kanker jenis tertentu [18].

Ekstraksi cair-cair adalah aplikasi dari kelarutan parsial untuk pemisahan campuran cair dari dua atau lebih komponen. Proses ekstraksi cair-cair diterapkan, secara umum untuk pemisahan campuran yang tidak dapat dilakukan oleh distilasi untuk satu atau lebih alasan:

a) Suhu distilasi yang terlalu tinggi.

b) Volatilitas relatif terlalu kecil atau adanya azeotrop.

c) Pemisahan berdasarkan volatilitas tidak memuaskan [19].

Ada banyak variasi campuran ekstraksi yang digunakan untuk mengekstrak likopen.
Tujuan dari ekstraksi adalah memisahkan likopen dari komponen larut air dari likopen yang berisi bahan makanan [6].

Sebuah larutan untuk dapat dikristalisasi harus berada pada kondisi sangat jenuh. Sebuah larutan di mana konsentrasi zat terlarut melebihi keseimbangan (jenuh), konsentrasi zat terlarut pada temperatur tertentu dikenal sebagai larutan jenuh. Ada empat metode utama untuk menghasilkan larutan sangat jenuh adalah sebagai berikut :

- Perubahan suhu (terutama pendinginan)

- Penguapan pelarut

- Reaksi kimia, dan

- Mengubah komposisi pelarut (misalnya dengan penggaraman)

Kristalisasi dari larutan dapat dianggap sebagai proses dua langkah. Langkah pertama adalah pemisahan fasa (pembentukan) dari kristal baru. Yang kedua adalah pertumbuhan kristal ini menjadi ukuran yang lebih besar. Kedua proses dikenal sebagai nukleasi dan pertumbuhan kristal. Analisis proses kristalisasi industri membutuhkan pengetahuan baik nukleasi maupun pertumbuhan kristal [1].

\section{Metodologi Penelitian}

Bahan yang digunakan dalam penelitian ini adalah jus tomat matang, etanol, metanol, heksana, dan etil asetat. Alat yang digunakan dalam penelitian ini meliputi labu leher tiga, refluks kondensor, statif dan klem, termometer, neraca analitik, labu leher tiga, corong pemisah, blender, hot plate, magnetic stirrer dan Fourier Transform Infrared Spectroscopy (FTIR).

\section{Persiapan Bahan Baku}

Buah tomat dicuci dengan air keran beberapa kali hingga bersih. Kemudian buah tomat dipotong - potong lalu dihaluskan menggunakan blender. Buah tomat yang telah dihaluskan kemudian disimpan di dalam chiller hingga digunakan.

\section{Ekstraksi}

Diukur $150 \mathrm{ml}$ sampel kemudian sampel diekstraksi selama 3 jam dengan pelarut heksana dengan perbandingan umpan:pelarut (1:2) pada temperatur $65{ }^{\circ} \mathrm{C}$. Ekstrak dan rafinat yang diperoleh dicuci dengan aquadest kemudian dimasukkan ke dalam corong pemisah untuk memisahkan ekstrak dan rafinat. Ekstrak dicuci dengan aquadest sambil diguncang untuk memisahkan ekstrak dengan pengotorpengotornya. Setelah terbentuk 2 lapisan, 
ambil semua lapisan atas (nonpolar) kemudian tampung ke dalam beaker glass.

\section{Kristalisasi dengan Antisolvent}

Semua lapisan atas (nonpolar) yang ditampung ke dalam beaker glass ditambahkan $100 \mathrm{ml}$ metanol sebagai antisolvent kemudian didiamkan beberapa jam hingga terbentuk kristal. Kristal yang terbentuk kemudian disaring menggunakan kertas saring Whattman No.1 setelah itu ditimbang massa kristal yang diperoleh.

\section{Hasil}

Karakterisasi FTIR (Fourier Transform Infra Red) Hasil Ekstraksi Likopen dari Buah Tomat dengan Penambahan Antisolvent

Karakterisasi FTIR (Fourier Transform Infra Red) hasil ekstraksi likopen dari buah tomat dengan penambahan antisolvent dilakukan untuk mengidentifikasi gugus fungsi dari senyawa likopen. Karakteristik FTIR dari hasil ekstraksi likopen dari buah tomat dengan penambahan antisolvent dapat dilihat pada Gambar 1 di bawah ini.

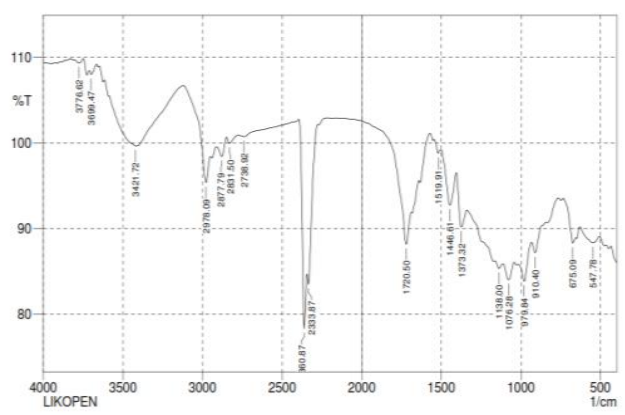

Gambar 2. Karakterisasi FTIR (Fourier Transform Infra Red) Hasil Ekstraksi Likopen dari Buah Tomat dengan Penambahan Antisolvent

Data spektrum likopen standar yang dianalisis dengan mencermati puncak serapan gelombang yang diperlihatkan puncak serapan pada daerah bilangan gelombang sebagai berikut : $956,72 \mathrm{~cm}^{-1}$; $1.373,36 \mathrm{~cm}^{-1} ; 1.456,30 \mathrm{~cm}^{-1} ; 1.647,26 \mathrm{~cm}^{-1}$; $1.743,71 \mathrm{~cm}^{-1} ; 2.879,82 \mathrm{~cm}^{-1} ; 2.910,68 \mathrm{~cm}^{-1}$; $3.392,90 \mathrm{~cm}^{-1}$. Spektrum dianalisis dengan mencermati puncak serapan gelombang yang diperlihatkan data spektrum puncak serapan pada bilangan gelombang sebagai berikut : bilangan gelombang 956,72 $\mathrm{cm}^{-1}$ menunjukkan gugus $\mathrm{R}-\mathrm{CH}=\mathrm{CH}-\mathrm{R}$ pada rantai likopen. Bilangan gelombang $1.373,36 \mathrm{~cm}^{-1}$ menunjukkan gugus $-\mathrm{CH}_{3}$ - pada rantai likopen. Bilangan gelombang $1.456,30 \mathrm{~cm}^{-1}$ menunjukkan vibrasi bending dari $-\mathrm{CH}_{2}$ - pada rantai likopen. Bilangan gelombang $1.647,26 \mathrm{~cm}^{-1}$ dan $1.743,71 \mathrm{~cm}^{-1}$ menunjukkan adanya ikatan $\mathrm{C}=\mathrm{C}$ pada rantai likopen. Bilangan gelombang 2.879,82 $\mathrm{cm}^{-1}$ dan 2.910,68 $\mathrm{cm}^{-1}$ menunjukkan gugus $\mathrm{C}-\mathrm{H}$ pada rantai likopen. Bilangan gelombang $3.392,90 \mathrm{~cm}^{-1}$ kemungkinan gugus $\mathrm{O}-\mathrm{H}$ dari uap air yang terikat pada likopen [2].

Maka dari hasil analisa FTIR ini dapat disimpulkan bahwa likopen yang dihasilkan memiliki gugus-gugus yang diharapkan.

\section{Pengaruh Perbandingan Umpan dan Pelarut (F/S) Heksana dan Jenis Antisolvent Terhadap Ekstraksi Likopen}

Berdasarkan penelitian yang telah dilakukan, pengaruh perbandingan umpan dan pelarut (F/S) heksana dan jenis antisolvent terhadap ekstraksi likopen dapat dilihat pada gambar berikut.

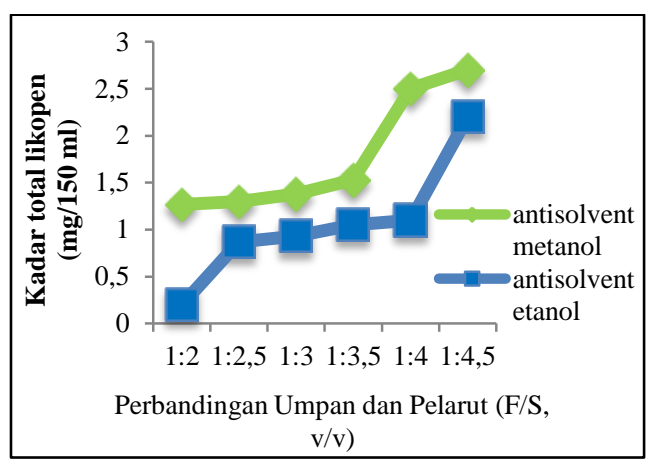

Gambar 3. Pengaruh Perbandingan Umpan dan Pelarut (F/S) Heksana dan Jenis Antisolvent terhadap Ekstraksi Likopen

Pada Gambar 3 dapat dilihat bahwa semakin besar perbandingan umpan dan pelarut (F/S) heksana yang digunakan maka kadar total likopen yang diperoleh semakin meningkat pula. Pada perbandingan umpan dan pelarut 1:4,5 diperoleh kadar total likopen paling tinggi baik pada antisolvent metanol maupun pada etanol yaitu 2,7 $\mathrm{mg} / 150 \mathrm{ml}$ dan 2,2 mg/150 $\mathrm{ml}$. Hal ini sesuai dengan teori bahwa jumlah likopen semakin meningkat dengan semakin besarnya volume pelarut [17]. Namun rendemen likopen yang terekstrak pada tomat masih sedikit, dimana kandungan likopen dalam buah tomat adalah 3.041 $\mu \mathrm{g} / 100$ gram buah tomat [11].

Rasio umpan dan pelarut yang tinggi menghasilkan ekstrak dalam jumlah besar, hal ini sesuai dengan prinsip perpindahan massa dimana driving force untuk 
perpindahan massa adalah gradien konsentrasi antara umpan dengan pelarut. Rasio umpan dan pelarut yang tinggi dapat mendukung peningkatan gradien konsentrasi, yang menghasilkan kenaikan laju difusi yang menyebabkan ekstraksi lebih optimal oleh pelarut $[8,13]$. Hal ini sejalan dengan Zhang et al. [16] yang menyatakan bahwa kesempatan komponen bio-aktif untuk melakukan kontak dengan solvent pengekstraksi semakin meningkat seiring dengan meningkatnya jumlah solvent pengekstrasi dan tidak akan berlanjut hingga tercapainya kesetimbangan. Partikel dengan volatilitas yang lebih tinggi mendorong sistem untuk mencapai keadaan lewat jenuh jauh lebih cepat, sehingga menurunkan ukuran partikel [20].
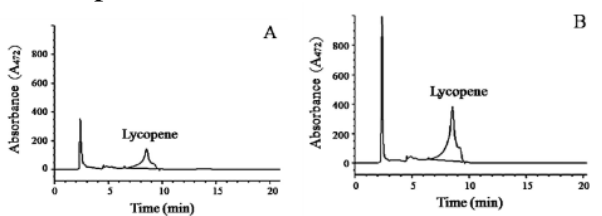

Gambar 4. Hasil Analisa HPLC Ekstraksi Likopen dari Buah Tomat Menggunakan Pelarut (A) Heksana dan (B) Etil Asetat [10]

Pada Gambar 4 dapat dilihat bahwa nilai absorbansi likopen hasil ekstraksi likopen menggunakan pelarut heksana lebih rendah bila dibandingkan dengan ekstraksi menggunakan pelarut etil asetat. Maka dari penelitian yang telah dilakukan, dapat disimpulkan bahwa hasil penelitian telah sesuai dengan teori.

Banyak metode kristalisasi yang telah digunakan pada industri farmasi, salah satunya adalah kristalisasi dengan antisolvent. Pada kristalisasi dengan antisolvent, pelarut kedua yang dikenal sebagai antisolvent ditambahkan pada pelarut utama, sehingga menyebabkan pengurangan kelarutan zat terlarut pada pelarut utama dan menciptakan driving force lewat jenuh. Perbedaan jenis antisolvent mempengaruhi ukuran kristal dan distribusi kristal. Kondisi lewat jenuh dan komposisi pelarut juga merupakan faktor penting yang mempengaruhi bentuk dan sifat kristal. Kelarutan terjadi maksimum dengan penggunaan metanol sebagai antisolvent dan semakin berkurang dengan bertambahnya rantai pada alkohol. Dengan penambahan alkohol, semakin tinggi tingkat kepolaran maka kristal akan semakin berlapis-lapis dibandingkan dengan alkohol dengan tingkat kepolaran rendah. Dengan penambahan metanol, kristal yang terbentuk akan berbentuk seperti plat, sedangkan dengan penambahan alkohol lain, kristal akan seperti jarum dengan serpihan-serpihan. Metanol dan etanol menghasilkan pembentukan kristal yang cepat [12].

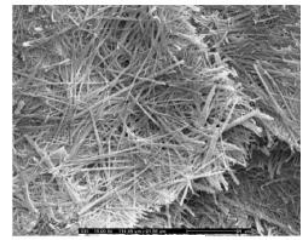

(a)

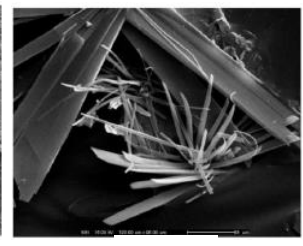

(b)
Gambar 5. Morfologi Kristal dengan Penambahan Antisolvent (a) Metanol dan (b) Etanol [12]

Metanol sebagai antisolvent memiliki koefisien partisi yang lebih tinggi daripada etanol dimana koefisien partisi berhubungan dengan daya pelarutan karetenoid dan trigliserida [10]. Maka dari penelitian yang telah dilakukan, dapat disimpulkan bahwa hasil penelitian telah sesuai dengan teori.

\section{Pengaruh Perbandingan Umpan dan Pelarut (F/S) Etil Asetat dan Jenis Antisolvent Terhadap Ekstraksi Likopen}

Berdasarkan penelitian yang telah dilakukan, pengaruh perbandingan umpan dan pelarut $(\mathrm{F} / \mathrm{S})$ etil asetat dan jenis antisolvent terhadap ekstraksi dapat dilihat pada gambar berikut.

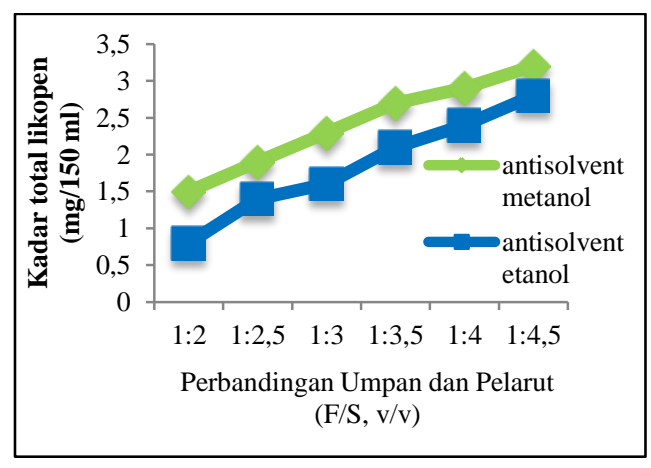

Gambar 6. Pengaruh Perbandingan Umpan dan Pelarut (F/S) Etil Asetat dan Jenis Antisolvent terhadap Ekstraksi Likopen

Pada Gambar 6 dapat dilihat bahwa semakin besar perbandingan umpan dan pelarut (F/S) etil asetat yang digunakan maka kadar total likopen yang diperoleh semakin meningkat. Pada perbandingan umpan dan pelarut 1:4,5 diperoleh kadar total likopen paling tinggi baik pada 
antisolvent metanol maupun pada etanol yaitu $3,2 \mathrm{mg} / 150 \mathrm{ml}$ dan $2,8 \mathrm{mg} / 150 \mathrm{ml}$. Hal ini sesuai dengan teori bahwa jumlah likopen semakin meningkat dengan semakin besarnya volume pelarut [17].

Kelarutan antioksidan dan laju perpindahan massa bervariasi tergantung dengan polaritas pelarut dan jumlah zat organik yang digunakan. Kelarutan komponen bioaktif kedalam pelarut adalah proses fisis, kesempatan komponen bioaktif untuk berkontak dengan pelarut meningkat jika perbandingan umpan dan pelarut semakin besar yang akan menyebabkan laju ekstraksi semakin besar [7]. Etil asetat sebagai pelarut yang bersifat polar sangat efektif untuk mengekstraksi antioksidan [22]. Setelah dilakukan percobaan dengan pelarut yang berbeda, etil asetat memiliki efisiensi ekstraksi yang terbaik. Hasil HPLC menunjukkan bahwa terdapat peak tajam untuk likopen, yang mengindikasikan bahwa tidak ada komponen atau kontaminan lain yang terdapat pada ekstrak. Dimana pelarut organik lain juga mengekstrak komponen lain selain likopen. Etil asetat juga lebih disukai karena harganya yang murah, tingkat toksisitasnya yang rendah dan baunya yang tidak menusuk [14]. Maka dari penelitian yang telah dilakukan, dapat disimpulkan bahwa hasil penelitian telah sesuai dengan teori.

Kristalisasi antisolvent adalah metode pemisahan dan pemurnian yang merupakan cara yang efektif untuk menghasilkan partikel berukuran nano [3]. Penggunaan antisolvent pada proses kristalisasi mengurangi kelarutan zat terlarut pada larutan dan menyebabkan terjadinya kristalisasi secara cepat. Paremeter kristalisasi sangat mempengaruhi mekanisme pembentukan partikel, ukuran kristal, dan distribusinya [9]. Maka dari penelitian yang telah dilakukan, dapat disimpulkan bahwa hasil penelitian telah sesuai dengan teori.

\section{Kesimpulan}

Adapun kesimpulan yang diperoleh dari penelitian ini adalah semakin besar perbandingan umpan dan pelarut maka kadar likopen yang diperoleh akan semakin besar karena bahwa jumlah likopen semakin meningkat dengan semakin besarnya volume pelarut. Rasio umpan dan pelarut yang tinggi dapat mendukung peningkatan gradien konsentrasi, yang menghasilkan kenaikan laju difusi yang menyebabkan ekstraksi lebih optimal oleh pelarut. Dengan penggunaan antisolvent metanol, kadar likopen yang diperoleh semakin besar dibandingkan dengan penggunaan etanol sebagai antisolvent karena metanol sebagai antisolvent memiliki koefisien partisi yang lebih tinggi daripada etanol dimana koefisien partisi berhubungan dengan daya pelarutan karetenoid dan trigliserida. Dan dengan penggunaan pelarut etil asetat, kadar likopen yang diperoleh semakin besar dibandingkan dengan penggunaan heksana sebagai pelarut.

\section{Daftar Pustaka}

[1] Bibliotek, Crystallization, www. sundoc. bibliothek.de, 2002, diakses pada 16 Mei 2014.

[2] D.L. Pavia, G.M. Lampman, dan Kriz, G.S., Introduction To Spectroscopy : A Guide for Students of Organic Chemistry, Singapore, p.102, 2001.

[3] D. Xia, P. Quan, H. Piao, S. Sun, Y. Yin, dan F. Cui, Preparation of Stable Nitrendipine Nanosuspensions Using the Precipitation-Ultrasonication Method for Enhancement of Dissolution and Oral Bioavailability, European Journal of Pharmaceutical Sciences, Vol.40, hal 325-334, 2010.

[4] Efsa, Safety of Lycopene Cold Water Dispersible Products from Blakeslea trispora, The EFSA Journal, Vol. 893, hal 1-15, 2008.

[5] Francisco Artes, Francisco Garcia, Jose Marquina, Antonio Cano, dan J. Pablo Fernandez Trujillo, Physiological Responses of Tomato Fruit to Cyclic Intermittent Temperature Regimes, Postharvest Biology and Technology, Vol.14, hal 283-296, 1998.

[6] Jannat M. Roldan-Gutierrez dan Maria Dolores Luque de Castro, Lycopene: The Need for Better Methods for Characterization and Determination, Trends in Analytical Chemistry, Vol.26, hal 163-170, 2007.

[7] J. Xi, Caffeine Extraction from Green Tea Leaves Assisted by High Pressure Processing, Journal of Food Engineering, Vol.94, hal 105-109, 2009.

[8] M.A. Al-Farsi dan Chang Y.L, Optimization of Phenolics and Dietary Fibre Extraction from Date Seeds, Food Chemistry, Vol.108, hal 977-985, 2007. 
[9] M. W. Park dan S. D. Yeo, Antisolvent Crystallization of Roxithromycin and the Effect of Ultrasound, Separation Science and Technology, Vol.45, hal 1402-1410, 2010.

[10] Myong-Kyun Roh, Min-Hee Jeon, JinNam Moon, Woi-Sook Moon, SunMee Park, dan Jae-Suk Choi, A Simple Method For The Isolation Of Lycopene From Lycopersicon Esculentum, Botanical Sciences, Vol.91, hal 187192, 2013.

[11] Nutrient Data Laboratory, ARS, USDA National Food and Nutrient Analysis Program Wave, Beltsville MD, 2001.

[12] Pornsak Sriamornsak dan Kanokporn Burapapadh, Characterization of Recrystallized Itraconazole Prepared by Cooling and Anti-Solvent Crystallization, Asian Journal of Pharmaceutical Sciences, hal 1-9, 2015.

[13] P.W.Tan, C.P.Tan dan Ho,C. W, Antioxidant Properties: Effect of Solidto-Solvent Ratio on Antioxidant Compounds and Capacities of Pegaga (Centella Asiatica), International Food Research Journal, Vol.18, hal 553-558, 2011.

[14] Saima Haroon, Extraction of Lycopene from Tomato Paste and its Immobilization for Controlled Release, The University of Waikato, 2014.

[15] Santi R. Bhowmik dan Jung C. Pan, Shelf Life of Mature Green Tomatoes Stored in Controlled Atmosphere and High Humidity, Journal of Food Science, Vol.57, hal 948-953, 1992.

[16] S.Q.Zhang, H.M.Bi dan C.J. Liu, Extraction of Bio-Active Components from Rhodiola Sachalinensis under Ultrahigh Hydrostatic Pressure, Separation and Purification Technology, Vol.57, hal 277-282, 2007.

[17] SR Kumar, Sundar SS, Afandi A dan Rahman S, Optimization of Lycopene From Malaysian All Sesason Coloured Fleshy Fruits, International Journal of Biology,

Pharmacy an Allied Sciences (IJBPAS), Vol.2, hal 1455-1467, 2013.

[18] T. Anguelova dan J. Warthsen, Lycopene Stability in Tomato Powders, Journal of Food Science, Vol.65, hal 67-70, 2000.

[19] Thomas W. Pratt, Liquid-Liquid Extraction, Journal of The American
Oil Chemists Society, Vol.30, hal 497505, 1953.

[20] Tu LS, Dehghani F dan Foster NR, Micronisation and Microencapsulation of Pharmaceuticals Using a Carbon Dioxide Antisolvent, Powder Technology, Vol.126, hal 134-149, 2002.

[21] Victor R. Preedy dan Ronald R. Watson, Tomatoes and Tomato Products, Science Publishers, Enfield, USA, 2008.

[22] W. Peschel, Sanchez-Rabaneda F., Dn W. Plescher A., Gartzia I., Jimenez D., Lamuela-Raventos R., Buxaderas S., Condina C, An Industrial Approach in the Search of Natural Antioxidants from Vegetable and Fruit Wastes, Food Chem, Vol.97, hal 137-150, 2006.

[23] Yvon Dumas, Mario Dadomo, Giuseppe Di Lucca dan Pascal Groiler, Effects of Environmental Factors and Agricultural Techniques on Antioxidant Content of Tomatoes, Journal of the Science of Food and Agriculture, Vol.83, hal 369-382, 2003. 